J. Lake Sci.(湖泊科学), 2009, 21(6): 834-838

http://www.jlakes.org. E-mail: jlakes@niglas.ac.cn

(C)2009 by Journal of Lake Sciences

\title{
太湖浮游植物群落的有机碳生产及其影响因子分析*
}

\author{
钱奎梅 ${ }^{1}$, 王丽萍 ${ }^{1}$, 陈宇炜 ${ }^{2 * *}$ \\ (1: 中国矿业大学环境与测绘学院, 徐州 221008) \\ (2: 中国科学院南京地理与湖泊研究所, 南京 210008)
}

摘 要: 2007年1-12月对中国科学院太湖湖泊生态系统站栈桥附近进行了每月 1 次以及太湖 4 个典型湖区每季度 1 次的有机碳 生产实验, 分析了太湖浮游植物群落的有机碳生产情况及其影响因子. 结果表明, 浮游植物有机碳生产与光照、温度以及浮游 植物的群落组成有着密切的关系. 春、夏季浮游植物光合效率比秋、冬季高, 空间上蓝藻占优势的湖区较高, 水草区较低. 关键词: 太湖, 浮游植物群落, 有机碳生产

\section{The production of organic carbon by phytoplankton in Lake Taihu and its influence factors}

QIAN Kuimei ${ }^{1}$, WANG Liping ${ }^{1} \&$ CHEN Yuwei $^{2}$

(1: China University of Mining \& Technology, Xuzhou 221008, P.R.China)

(2: Nanjing Institute of Geography and Limnology, Chinese Academy of Sciences, Nanjing 210008, P.R.China)

Abstract: The organic carbon production of phytoplankton near the Trestle monthly and at four stations quarterly in Lake Taihu from January 2007 to December 2007 was investigated, and its influence factors were analyzed. The results showed that there were obvious temporal and spatial differences in the production of organic carbon in Lake Taihu. The high values of organic carbon production were recorded in spring and summer. The production of organic carbon was higher in the area where the phytoplankton was dominated by Cyanophyta and lower in the aquatic areas.

Keywords: Lake Taihu; phytoplankton community; production of organic carbon

水生生态系统的有机物来源包括内源和外源两部分. 内源有机物是水体内部生产者(藻类和水生高 等植物)利用光合作用产生的, 外源有机物是由其他生态系统(主要是陆地生态系统)生产并通过不同途径 传输到水体中的 ${ }^{[1]}$. 大量的研究表明, 有机碳是水生生态系统中最大的有机物库. 因此, 水体中有机碳的 产生和传输利用成为生态系统物质转化和能量流动的关键环节 ${ }^{[2]}$. 由于浅水湖泊生态系统各营养级生物 之间的关系相对比较复杂, 要弄清其能量流动的过程就相对困难, 至今世界范围内有关浅水湖泊有机碳 的生态过程的研究鲜见报道.

浮游植物是水生生态系统的主要初级生产者, 其通过光合作用将无机碳(主要是二氧化碳)合成为有 机物, 同时将太阳能转化为化学能储存, 成为地球上生物的主要能量来源. 浅水湖泊的有机碳来源包括 水体内部浮游植物的光合作用生产的和除此以外的任何其他来源(包括水生高等植物和陆生植物光合作 用生产后传输而来的部分).

湖泊中浮游植物对有机碳的生产过程十分复杂, 不仅受光照、温度、营养盐、浮游植物生物量等环境 因子的影响, 不同的测定方法和手段得到的结果也有差异. 目前常用的方法有黑白瓶测氧法、碳同位素法、 叶绿素法等. 黑白瓶法简便易行, 应用广泛. 浮游植物对有机碳的生产通常通过初级生产力来表征.

太湖作为我国第三大淡水湖，具有浅水湖泊的各种特性，例如水体浑浊、垂直交换快、水土-水气界面交

* 国家重点基础研究发展计划(973)项目(2008CB418005)和国家自然科学基金项目(30670405)联合资助. 2009-03-09 收稿; 2009-06-01 收修改稿. 钱奎梅, 女, 1982 年生, 博士研究生; E-mail: qiankuimei@163.com.

** 通讯作者; E-mail: ywchen@niglas.ac.cn. 
换充分、外源营养负荷高等, 也包含了中国多数浅水湖泊的共性, 即水体富营养化和蓝藻水华暴发. 而太湖的 不同湖区又可以代表不同类型的浅水湖泊. 因此, 在太湖开展浮游植物有机碳的研究具有良好的典型性.

\section{1 材料与方法}

\section{1 采样地点}

本实验对中国科学院太湖湖泊生态系统研 究站的栈桥附近进行每月一次的浮游植物有机 碳生产测定. 另外, 还选取了太湖常规监测的 4

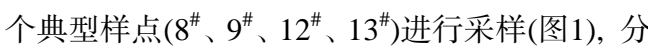
别进行了每个季度一次的浮游植物有机碳生产 的测定. 其中, $8^{\#}$ 位于太湖湖心区，湖心区湖面 广阔，受风力作用较大. $9^{\#}$ 位于五里湖湖区，五 里湖是太湖北部的一个湖湾, 20 世纪 90 年代以 来, 由于大量生活、工业污水人湖, 五里湖水质 越来越差，水生态受到严重破坏，水草死亡，水 体严重富营养化. $12^{\#}$ 位于东太湖，东太湖是一 个典型的草型湖区, 水草较多, 藻类生物量较 少. $13^{\#}$ 位于贡湖湾, 贡湖湾是一个藻草混合型 湖区. 为了对照野外和室内浮游植物对有机碳 的产生情况, 我们还设计了一组室内培养的浮 游植物有机碳生产实验.

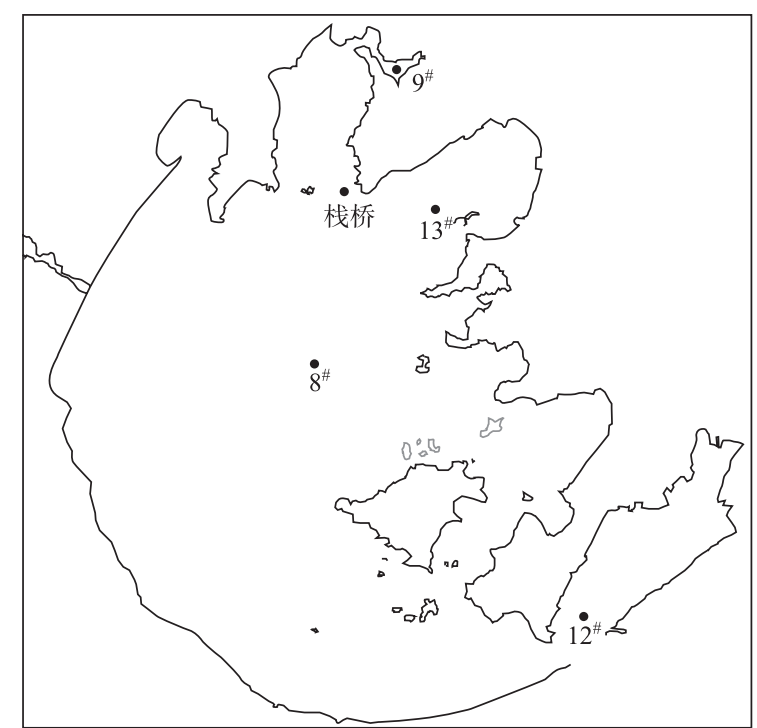

图 1 太湖采样点示意图

Fig.1 The sampling sites in Lake Taihu

\section{2 采样及测量方法}

1.2.1 有机碳生产测定 实验于 2007 年 1-12 月用黑白瓶溶氧法测定，曝光时段都是 10:00-14:00, 曝光在 太湖湖泊生态系统研究站栈桥平台上进行, 另外, 每个季度对 $8^{\#}, 9^{\#}, 12^{\#}, 13^{\#}$ 的有机碳生产进行测定, 事 先将 $8^{\#}, 9^{\#}, 12^{\#}, 13^{\#}$ 点的水样都取到栈桥平台上, 然后统一曝光进行有机碳生产的测定. 黑白瓶体积为 $250 \mathrm{ml}$, 挂瓶深度分别为 $0 、 20 、 40 、 60$ 和 $100 \mathrm{~cm}$, 每层 1 个黑瓶、2 个白瓶，挂瓶水样为各层水的混合 水样, 采样时固定初始溶解氧，同时测定水温、透明度、光合有效辐射强度、浮游植物叶绿素 a(Chl.a)含 量及氮、磷营养盐浓度. 光强选用美国 LI-cor 公司生产的水下光量子仪测定，透明度用赛氏圆盘测定. 叶 绿素 a 采用分光光度法 ${ }^{[3]}$, 利用 $90 \%$ 的酒精萃取, 然后在 721 分光光度计上测定. 其他营养盐指标的测定 参见《湖泊生态调查观测与分析》 ${ }^{[4]}$.

1.2.2 室内培养的有机碳生产的实验步骤 配制 BG-11 培养基, 装人 3L 的三角瓶中, 加人一定量的微囊藻, 预先设定几组不同的叶绿素 $\mathrm{a}$ 浓度, 对于本实验, 为了表明不同温度和辐射对有机碳生产的影响, 设计了 4 种不同的实验条件, A1 白瓶放在温室内自然光直射的位置, 这种条件下, 温度高、光照强; A2 白瓶放在温室 内没有自然光直射的位置, 这种条件下, 温度高、光照弱; A3 白瓶放在温室外自然光直射的位置, 这种条件 下，温度低、光照强; A4 白瓶放在温室外没有自然光直射的位置, 这种条件下, 温度低、光照弱.

\section{3 水生态系统有机碳生产的计算方法}

水柱日生产量 $\left(\mathrm{g}\left(\mathrm{O}_{2}\right) / \mathrm{m}^{2}\right)$ 及其计算方法: 水柱日生产量是指面积为 $1 \mathrm{~m}^{2}$, 从水表面到水底的整个柱形 水体的日生产量, 可用算术平均值累计法计算. 可以用当量关系将产氧量乘以系数 0.35 粗略换算为该水 域的有机碳生产量, 也可将氧量换算为生产有机物的量, 即乘以系数 9/8 即得. 光合效率为每一层的初级 生产率与叶绿素 a 浓度的比值.

\section{2 结果与讨论}

\section{1 各月有机碳生产的变化趋势}

栈桥平台附近浮游植物有机碳生产的情况(图 2)可以看出, 生产量和呼吸量在夏、秋季较高, 而在冬、 
春季较低. 8 月的总生产量达到了最大值, $0.140 \mathrm{mg} /(\mathrm{L} \cdot \mathrm{h}), 5$ 月的总生产量次之, $0.128 \mathrm{mg} /(\mathrm{L} \cdot \mathrm{h}), 1$ 月的总生 产量为最小值, $0.014 \mathrm{mg} /(\mathrm{L} \cdot \mathrm{h})$.

夏、秋季的光合效率较高, 而冬、春季较低, 说明夏、秋季的温度和光照条件适合于浮游植物的生 长(图 3).

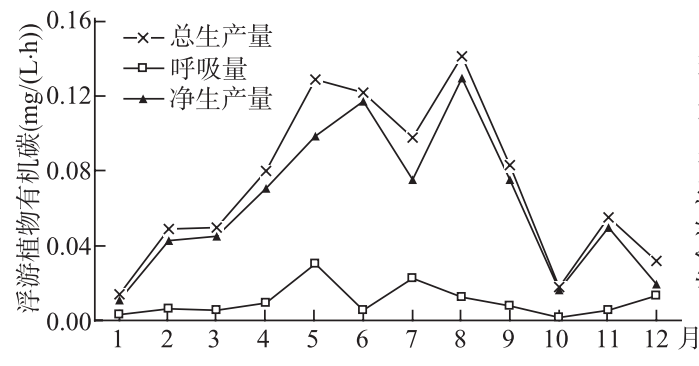

图2 2007年栈桥附近浮游植物有机碳生产的变化

Fig.2 The production of organic carbon in Lake Taihu near trestle in 2007

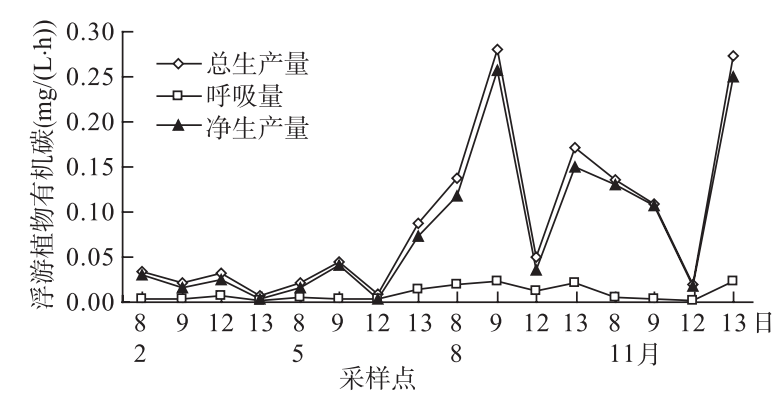

图 42007 年太湖 4 个典型湖区有机碳生产情况

Fig. 4 The production of organic carbon of four representative areas in Lake Taihu in 2007

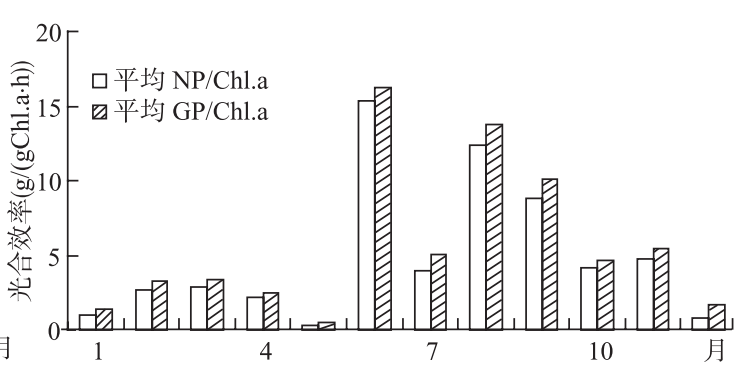

图 32007 年浮游植物有机碳的光合效率

Fig.3 The photosynthetic efficiency of organic carbon in Lake Taihu in 2007

太湖四个典型湖区每季度的有机碳生产 情况说明(图 4), 夏、秋季的总生产量和呼吸 量较高, 而冬、春季较低. 空间上, $8^{\#}$ 和 $9^{\#}$ 点 的有机碳生产量较高. 8 月 $9^{\#}$ 点的总生产量 达到了最大值, $0.281 \mathrm{mg} /(\mathrm{L} \cdot \mathrm{h}), 11$ 月 $13^{\#}$ 的总 生产量次之, $0.273 \mathrm{mg} /(\mathrm{L} \cdot \mathrm{h}), 2$ 月 $13^{\#}$ 为最小值, $0.007 \mathrm{mg} /(\mathrm{L} \cdot \mathrm{h})$.

浮游植物生物量是有机碳生产的物质基 础. 浮游植物的生物量也常用叶绿素 $\mathrm{a}$ 的浓度 来表示. 栈桥附近水体的浮游植物叶绿素 $\mathrm{a}$ 含 量基本上是春、夏季高, 秋、冬季低. 近几年 来, 太湖富营养化严重，蓝藻暴发 ${ }^{[5]}$.太湖

夏、秋季蓝藻暴发严重, 再加上风力作用, 蓝藻水华由于风浪作用在栈桥附近大量聚集, 导致栈桥附近的 浮游植物叶绿素a含量很高. 另外, 由于2007年12月有机碳生产的测定时, 由于风浪的作用, 使得蓝藻都 聚集到了栈桥附近, 导致栈桥附近的叶绿素 $\mathrm{a}$ 含量较高. 因此, 蓝藻占优势的区域浮游植物叶绿素 $\mathrm{a}$ 的浓 度较高, 而水草区由于浮游植物较少, 浮游植物通过叶绿素合成的有机碳也较少, 因此, 有机碳生产率 的变化与浮游植物叶绿素 $\mathrm{a}$ 含量的变化较为一致.

空间上，由于太湖是一个大型的浅水湖泊，水面广阔，太湖的不同湖区可以代表不同类型的浅水湖 泊(例如, 贡湖湾 $\left(13^{\#}\right)$ 代表藻-草混合型湖泊, 东太湖(12 $)$ 代表草型湖泊). $8^{\#} 、 13^{\#}$ 样点叶绿素a的含量显著 高于其他样点, 尤其 5 月份的 $13^{\#}$, 最高值达到了 $103 \mu \mathrm{g} / \mathrm{L}$. $12^{\#}$ 在东太湖, 由于东太湖是草型湖泊, 其中浮 游植物较少, 因此叶绿素 $\mathrm{a}$ 含量较低. $8^{\#}$ 位于太湖湖心, 由于太湖的水面广阔, 11月份风力的作用, 将浮游 植物都聚集到湖心位置, 因此, 11月份的叶绿素 $\mathrm{a}$ 含量非常高, 达到了 $339.5 \mathrm{\mu g} / \mathrm{L}$. 到冬季 4 个采样点的叶绿 素 $\mathrm{a}$ 含量较低, 这是由于冬季温度低、光强弱, 浮游植物处于休眠越冬期, 光照和温度限制其生长, 因而叶 绿素 $\mathrm{a}$ 含量都很低. 有机碳生产的时空分布与叶绿素 $\mathrm{a}$ 的时空分布较为一致, 冬、春季低, 夏、秋季高. 结果 表明, 浮游植物的有机碳生产情况存在明显的季节变化和空间差异, 这与张运林等 ${ }^{[6]}$ 的研究结果一致.

\section{2 室内培养的有机碳生产}

利用前期纯培养的微囊藻进行有机碳生产的实验. 取一定体积的原培养液放到新配制好的培养基中, 测定其中的叶绿素 $\mathrm{a}$ 的浓度. 在本实验中, 选取浮游植物的 2 个浓度梯度进行实验, 并测定其中的叶绿素 
a 浓度分别为 $800 \mu \mathrm{g} / \mathrm{L}$ (浓)和 $200 \mu \mathrm{g} / \mathrm{L}$ (稀).

室内培养的有机碳生产实验于 2007 年 12 月 13 日进行, 实验过程中 A1、A2、A3、A4 4 个不同条件 的辐射和气温数据如表 1 所示.

表 1 2007-12-13 的辐射和气温数据

Tab.1 The radiation and temperature on December 13, 2007

\begin{tabular}{ccccccc}
\hline 时间 & $\begin{array}{c}\mathrm{A} 1 \text { 辐射 } \\
\left(\mu \mathrm{E} /\left(\mathrm{m}^{2} \cdot \mathrm{s}\right)\right)\end{array}$ & $\begin{array}{c}\mathrm{A} 2 \text { 辐射 } \\
\left(\mu \mathrm{E} /\left(\mathrm{m}^{2} \cdot \mathrm{s}\right)\right)\end{array}$ & $\begin{array}{c}\text { 室内温度 } \\
\left({ }^{\circ} \mathrm{C}\right)\end{array}$ & $\begin{array}{c}\mathrm{A} 3 \text { 辐射 } \\
\left(\mu \mathrm{E} /\left(\mathrm{m}^{2} \cdot \mathrm{s}\right)\right)\end{array}$ & $\begin{array}{c}\mathrm{A} 4 \text { 辐射 } \\
\left(\mu \mathrm{E} /\left(\mathrm{m}^{2} \cdot \mathrm{s}\right)\right.\end{array}$ & $\begin{array}{c}\text { 室外温度 } \\
\left({ }^{\circ} \mathrm{C}\right)\end{array}$ \\
\hline $12: 00$ & 430 & 20 & 18.5 & 620 & 130 & 8 \\
$13: 00$ & 265 & 15.5 & 19.6 & 400 & 105 & 9.5 \\
$14: 00$ & 185.5 & 12.5 & 19.5 & 300 & 100 & 9 \\
$15: 00$ & 63 & 4.5 & 17.8 & 70 & 30 & 8 \\
$15: 40$ & 35 & 2.5 & 17 & 56 & 29 & 8 \\
\hline
\end{tabular}

纯种微囊藻的有机碳生产情况可以看出(图 5a), 叶绿素 a浓度高的水样, 其中的总初级生产量和净初 级生产量都很高. 由于本实验是用培养基进行培养的, 培养基中的营养盐浓度都是很高的, 足够其中的 浮游植物生长所利用. 另外, 叶绿素 $\mathrm{a}$ 的浓度可以用来表征其中浮游植物的生物量. 因此, 叶绿素 a 浓度 高的, 表明其中的浮游植物多, 合成有机碳的产量高. 纯种微囊藻的光合效率可以看出(图 5b), 光合效率 与培养溶液浮游植物的浓度关系不大, 而是受到辐射和水温的影响. 从本实验的结果来看, A1 的光合效 率最高, 由此, 在本实验条件下, 光照越强, 温度越高, 光合效率越高. 在 A3 条件下, 对于浮游植物生物 量高的培养溶液来说, 辐射对光合效率影响较大, 而对于浮游植物生物量低的培养溶液来说, 虽然辐射 够强, 但是由于室外温度较低, 光合效率也低.
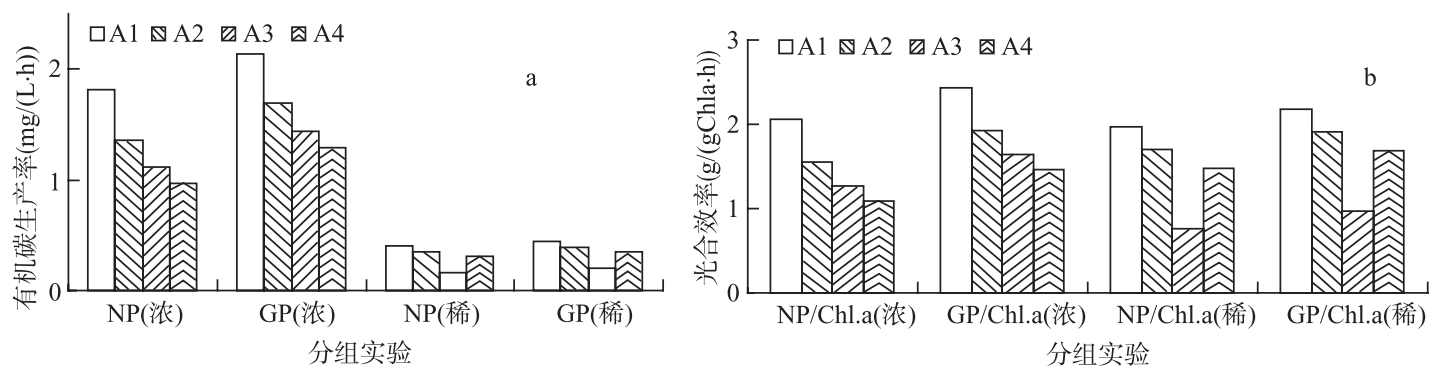

图 5 纯种微囊藻的有机碳生产(a)和光合效率(b)(NP 代表净初级生产力, GP 代表总初级生产力)

Fig.5 The production of organic carbon(a) and photosynthesis efficiency(b) of Microcystis

\section{3 浮游植物群落生长过程中环境因子的作用}

浮游植物生长是一个多因素综合作用的过程, 影响因子主要有营养因子、生态因子. 对绝大多数水 体而言, 限制浮游植物生长的营养因子主要是氮和磷, 有时 $\mathrm{CO}_{2}$ 也会成为限制因素, 生态因子是浮游植 物生长的外因, 主要包括光照、温度、 $\mathrm{pH}$ 值、溶解氧、水的活度、氧化还原电位、其它生物等.

太湖水体中总氮浓度在冬、春季较高，而在夏、秋季有所降低. 而总磷的浓度总体变化不大，只有 6 月和 12 月份稍高. 有机碳生产率随光强变化而变化, 同一天内, 温度、营养盐、浮游植物现存量、滤食 性动物差异较小, 浮游植物有机碳生产率的日变化受光照的影响最大. 就整个水柱而言, 有机碳生产率 随光照增强而增大, 在中午 10:00-14:00 光照最强, 此时浮游植物有机碳生产率占一天累积总量的份额也 最大, 约为 $60 \%$. 就表层水而言, 中午前后光照最强时经常会出现光抑制现象(图 6), 除此之外一般有机 碳生产率随水深增加而下降 (图 6a), 这些结果与赵文等 ${ }^{[7]}$ 、阎喜武等 ${ }^{[8]}$ 结果一致, 与张运林等 ${ }^{[9-10]}$ 在室内 模拟而得到的强光作用下有机碳生产量最大值出现在 $0.2 \mathrm{~m}$ 处的结论也较为一致. 光强和有机碳生产量 
都是随深度的增加而递减，这与张运林等的 ${ }^{[9]}$ 结果一致. 最大光强出现在水表面，而有机碳生产量最大 值在晴天常不出现在表层, 出现在水下某一水层, 在太湖这一水层大概在 $20-50 \mathrm{~cm}$ 处 ${ }^{[11]}$. 表层光强太强, 光合作用受到抑制, 致使有机碳生产量较低, 但在阴天有机碳生产量最大值常常出现在表层 ${ }^{[10]}$.

除了光照之外, 温度在浮游植物的日生产量变化中也起着重要的作用 ${ }^{[10,12]}$. 在温度 $10^{\circ} \mathrm{C}$ 以上时, 浮游 植物便开始生长. 随着温度的升高, 其生长速度增长加快. 浮游植物生长的最适范围是在 $20^{\circ} \mathrm{C}$ 左右, 因为在 这个温度下, 浮游植物体内酶的活性最高. 在 $10-25^{\circ} \mathrm{C}$ 之间, 叶绿素 $\mathrm{a}$ 含量随着温度的升高而升高. 太湖单位 叶绿素 $\mathrm{a}$ 的日总生产力在 $24^{\circ} \mathrm{C}$ 附近有最大值, 因此认为 $25^{\circ} \mathrm{C}$ 条件是太湖有机碳生产的适宜温度 ${ }^{[12]}$. 据张运 林等 ${ }^{[10]}$ 的研究, 在 $10-30^{\circ} \mathrm{C}$ 之间有机碳生产量基本上随温度的上升而增加.
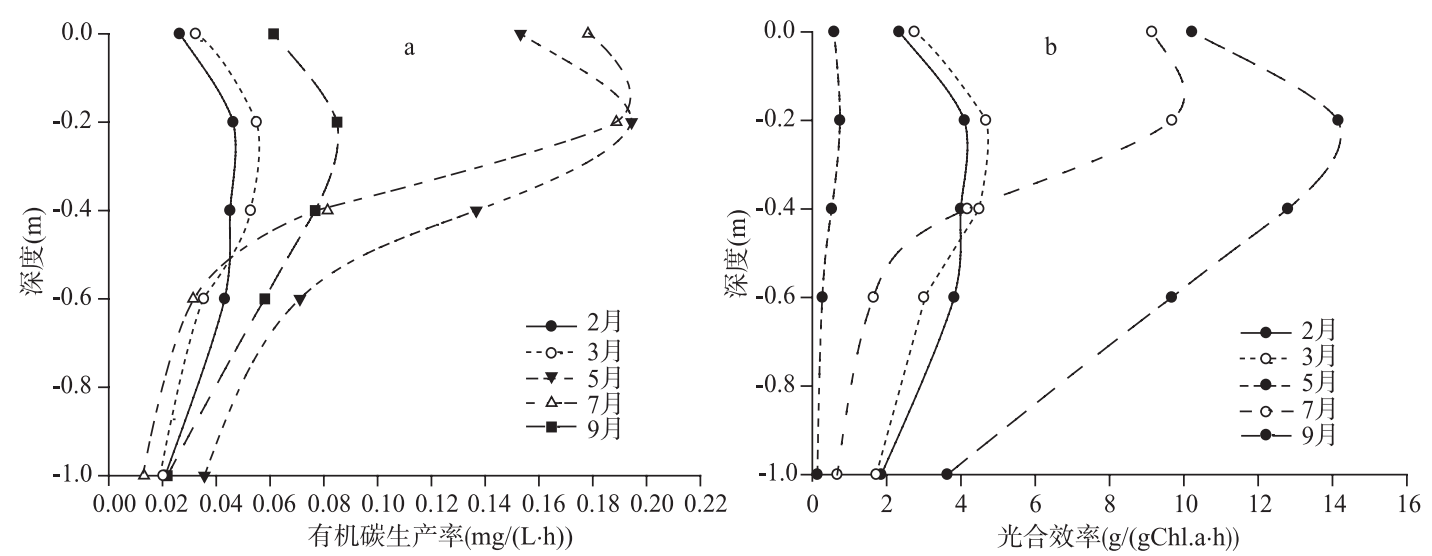

图6 2007年太湖栈桥附近有机碳生产的垂直分布(a)和光合效率(b)

Fig.6 The vertical distribution(a) and photosynthesis efficiency(b) of the organic carbon production in the platform of Lake Taihu in 2007

致谢: 本实验在中国科学院太湖湖泊生态系统研究站进行, 期间得到了太湖站季江、钱荣树、黄建明、 薛静琛等工程师无私的帮助, 特此感谢.

\section{3 参考文献}

[1] Baines SB, Pace ML. The production of dissolved organic matter by phytoplankton and its importance to bacteria: Patterns across marine and freshwater systems. Limnol \& Oceanogr, 1991, 36: 1078-1090.

[2] Amon RMW, Benner R. Bacterial utilization of different size classes of dissolved organic matter. Limnol \& Oceanogr, 1996 , 41: 41-51.

[3] 陈宇炜, 陈开宁, 胡耀辉. 浮游植物叶绿素a测定的“热乙醇法”及其测定误差的探讨. 湖泊科学, 2006, 18(5): 550-552.

[4] 黄祥飞. 湖泊生态调查观测与分析. 北京: 中国标准出版社, 2000: 33-245.

[5] 陈宇炜, 高锡云, 秦伯强. 西太湖北部夏季藻类种间关系的初步研究. 湖泊科学, 1998, 10(4): 35-40.

[6] 张运林, 秦伯强, 陈伟民等. 太湖梅梁湾浮游植物叶绿素 a 和初级生产力. 应用生态学报, 2004, 15(11): $2127-2131$.

[7] 赵 文, 董双林, 张兆琪等. 盐碱池塘浮游植物初级生产力日变化的研究. 应用生态学报, 2003, 14(2): $234-236$.

[8] 阎喜武, 何志辉. 虾池浮游植物初级生产力的研究. 中国渔业, 1997, 21(3): 288-295.

[9] 张运林, 秦伯强, 陈伟民等. 悬浮物浓度对水下光照和初级生产力的影响. 水科学进展, 2004, 15(5): 615-620.

[10] 张运林, 秦伯强, 陈伟民等. 太湖梅梁湾浮游植物叶绿素a和初级生产力. 应用生态学报, 2004, 15(11): $2127-2131$.

[11] 杨顶田, 陈伟民, 陈宇炜等. 太湖梅梁湾水体中初级生产力的光学检测. 湖泊科学, 2002, 14(4): 363-368.

[12] 张 立, 陈伟民. 影响浮游植物初级生产力的因素. 见: 秦伯强, 胡维平, 陈伟民等编. 太湖水环境演化过程与机理. 北 京: 科学出版社, 2004: 229-266. 